\title{
Pengaruh Penggunaan Agregat Kasar Kerikil Alami Terhadap Mutu Beton
}

\author{
Sena Arian ${ }^{1}$, Roestaman $^{2}$, Sulwan Permana ${ }^{3}$ \\ Jurnal Konstruksi \\ Sekolah Tinggi Teknologi Garut \\ Jl. Mayor Syamsu No. 1 Jayaraga Garut, 44151 Indonesia \\ Email:jurnal@sttgarut.ac.id \\ 11611018@sttgarut.ac.id \\ ${ }^{2}$ roestaman@sttgarut.ac.id \\ ${ }^{3}$ sulwanpermana@sttgarut.ac.id
}

\begin{abstract}
Abstrak - Sungai menghasilkan agregat dengan karakteristik yang berbeda, khususnya Kabupaten Garut dilalui oleh Sungai Cimanuk. Sungai Cimanuk mempunyai pola aliran yang berbeda-beda, sehingga kualitas agregat yang dihasilkan juga berbeda- beda. Setiap pola aliran menghasilkan material kerikil sungai yang bisa digunakan untuk campuran agregat kasar pada campuran pembuatan beton. Penggunaan struktur beton menyebabkan tingginya permintaan material, dibutuhkan inovasi guna mencari pengganti agregat. Agregat alami menjadi pilihan untuk bahan campuran beton, salah satunya agregat alami adalah kerikil alami yang berasal dari sungai. Penulis meneliti pengaruh dari penggunaan kerikil alami sebagai agregat bu pada campuran beton yang dikombinasikan dengan agregat (Spilt Ex. Garut). Proses dalam penelitian ini di Uji Laboratorium STT-Garut. Agregat kerikil alami hasil produksi langsung dari Sungai Cimanuk. Penggunaan kerikil alami pada campuran beton yang divariasikan menjadi 5, 10\%, dan 15\% digunakan rancangan mix design SNI 7833-2012. Berdasarkan nilai kuat tekan yang dianalisis menggunakan trendline dan pembatasan $\pm 5 \%$ untuk mendapat hasil nilai relevan menujukan adanya peningkatan pada campuran variasi $5 \%$ sebesar $1,81 \%, 0,87 \%$ pada variasi $10 \%, 8,72 \%$ dan 3,01 pada variasi $15 \%$.
\end{abstract}

Kata Kunci - Agregat; Beton; Kerikil Alami; Kuat Tekan.

\section{PENDAHULUAN}

\section{A. Latar Belakang}

Beton merupakan salah satu bahan konstruksi yang umum digunakan untuk bangunan gedung, jembatan, jalan dan bangunan lainnya. Beton dalam ilmu Teknik Sipil, merupakan bahan bangunan komposit yang terbuat dari kombinasi agregat. Bentuk yang paling umum dari beton adalah Agregat kasar, Agregat halus, semen dan air. Seiring berkembangnya teknologi beton dibidang konstruksi Penerapan metode baru dilakukan demi memperoleh hasil yang optimal maka dari itu dalam suatu pembangunan gedung maupun bangunan lainnya tidaklah lepas dari peran penggunaan beton tersebut. Namun perlu disadari mutu kualitas beton dipengaruhi oleh kualitas agregat [1].

Kualitas beton dipengaruhi oleh kualitas agregat, dan sifat agregat akan bervariasi sesuai dengan kondisi geologi, geografis dan iklim. Agregat menyumbang 60-70\% dari total volume beton, sehingga kualitas agregat sangat mempengaruhi kualitas beton [2]. Agregat yang paling umum digunakan adalah pasir dan kerikil alami. Sungai masih merupakan sungai yang paling umum dan memuaskan karena sedimen ini memiliki kemiringan konstan sebagai kemampuan selektif sungai [3]. Dengan geografi, geologi dan iklim tropis, sebagian besar wilayah Indonesia terpapar jalan pegunungan, dan jenis batuan alam di sungai sangat kaya [4]. Sungai menghasilkan agregat dengan karakteristik yang berbeda, khususnya Kabupaten Garut dilalui oleh Sungai 
Cimanuk. Sungai Cimanuk mempunyai pola aliran yang berbeda-beda, sehingga kualitas agregat yang dihasilkan juga berbeda-beda. Setiap pola aliran menghasilkan material kerikil sungai yang bisa digunakan untuk campuran agregat kasar pada campuran pembuatan beton dan akan berpengaruh terhadap mutu beton yang dihasilkan. Proses pembuatan beton perlu memperhatikan kuatan, ekonomis, dan durabilitas bahan dari beton tersebut. Berdasarkan dari beberapa hal tersebut penulis akan meneliti pengaruh penggunanaan kerikil sungai sebagai subtitusi pada agregat kasar campuran beton. Proses dalam penelitian ini akan di Uji di Laboratorium Sekolah Tinggi Teknologi Garut. Agregat halus dan kerikil sungai yang digunakan berasal dari Tambang Pasir Sungai Cimanuk Jager. Penggunaan kerikil sungai pada campran beton yang divariasikan, diharapkan akan mendapatkan Kualitas beton terbaik dapat menggantikan pekerjaan beton lainnya.

\section{B. Rumusan Masalah}

Untuk rumusan masalah pada penelitian ini adalah sebagai berikut:

1) Bagaimana sifat-sifat beton menggunakan agregat kasar kerikil alami dengan presentase $5 \%$, $10 \%$, dan $15 \%$ dibandingkan dengan sifat-sifat beton mutu fc' 20 MPa dengan 100\% agregat kasar normal?

2) Bagaimana mengetahui agregat kasar jenis kerikil alami bisa digunakan sebagai bahan campuran beton struktur?

\section{Tujuan Penelitian}

Tujuan utama dari penelitian ini adalah untuk mengetahui jenis agregat kasar yang menggunakan agregat alam sebagai pengganti agregat kasar pecah untuk mendapatkan pengaruh kualitas beton struktural..

\section{URAIAN PENELITIAN}

\section{A. Deskripsi Beton}

Beton adalah suatu komponen atau ikatan dari material bahan pembentuk yang terdiri dari campuran air, semen, dan agregat. Untuk menghasilkan atau membentuk beton yang sesuai rencana, diperlukan suatu campuran untuk menentukan dari masing-masing bahan yang dibutuhkan. Sifat atau karakteristik pada beton ini adalah kuat terhadap tekannya akan tetapi lemah terhadap tarik[5].

\section{B. Kerikil Alami}

Kerikil alami diperoleh melalui proses alami, yaitu melalui pengikisan tepian sungai dan dasar sungai dengan mengalirkan air sungai. Proses pembentukan ini terjadi karena pengendapan material batuan yang disebabkan oleh pelapukan. Bahan lapuk ini bisa berupa bahan organik atau mineral. Kemudian material tersebut dipadatkan dan dikonsolidasikan [6].

\section{Kuat Tekan Beton}

Sifat dari beton ini adalah mempunyai Kuat tekan lebih tinggi dari pada kuat tarik, maka kekuatan dalam beton akan mencapai batas maksimum setelah beton mencapai umur 28 hari. Ada beberapa hal diantaranya yang dapat mempengaruhi kuat tekan pada beton diantaranya adalah sebagai berikut.

1) Sifat Agregat

Agregat pada camputran beton menempati $60-70 \%$ dari keseluruhan total volume beton, oleh sebab itu agregat sangatlah berpengaruh terhadap kualitas dan sifat beton. Beberapa sifat agregat yang dapat mempengaruhi beton seperti ukuran maksimum agregat, kekuatan dan tekstur permukaan agregat.

2) Rasio Air Semen (FAS).

Semakin tinggi faktor air semen maka semakin rendah kekuatan beton yang dihasilkan, demikian sebaliknya jika faktor air semen rendah maka kekuatan beton yang dihasilkan akan lebih tinggi.

\section{3) Umur Beton}


Umur beton sangat berpengaruh terhadap kekuatannya, kekuatan beton ini akan semakin meningkat dari mulai beton tersebut di buka dari cetakan setelah 24 jam. Akan tetapi kekuatan beton akan berhenti setelah mencapai batas maksimumnya, batas maksimum kekuatan beton ini terjadi

\section{Metode Penelitian}

Proses atau tahapan yang dilakukan dalam penelitian ini dapat dilihat pada Gambar 1.

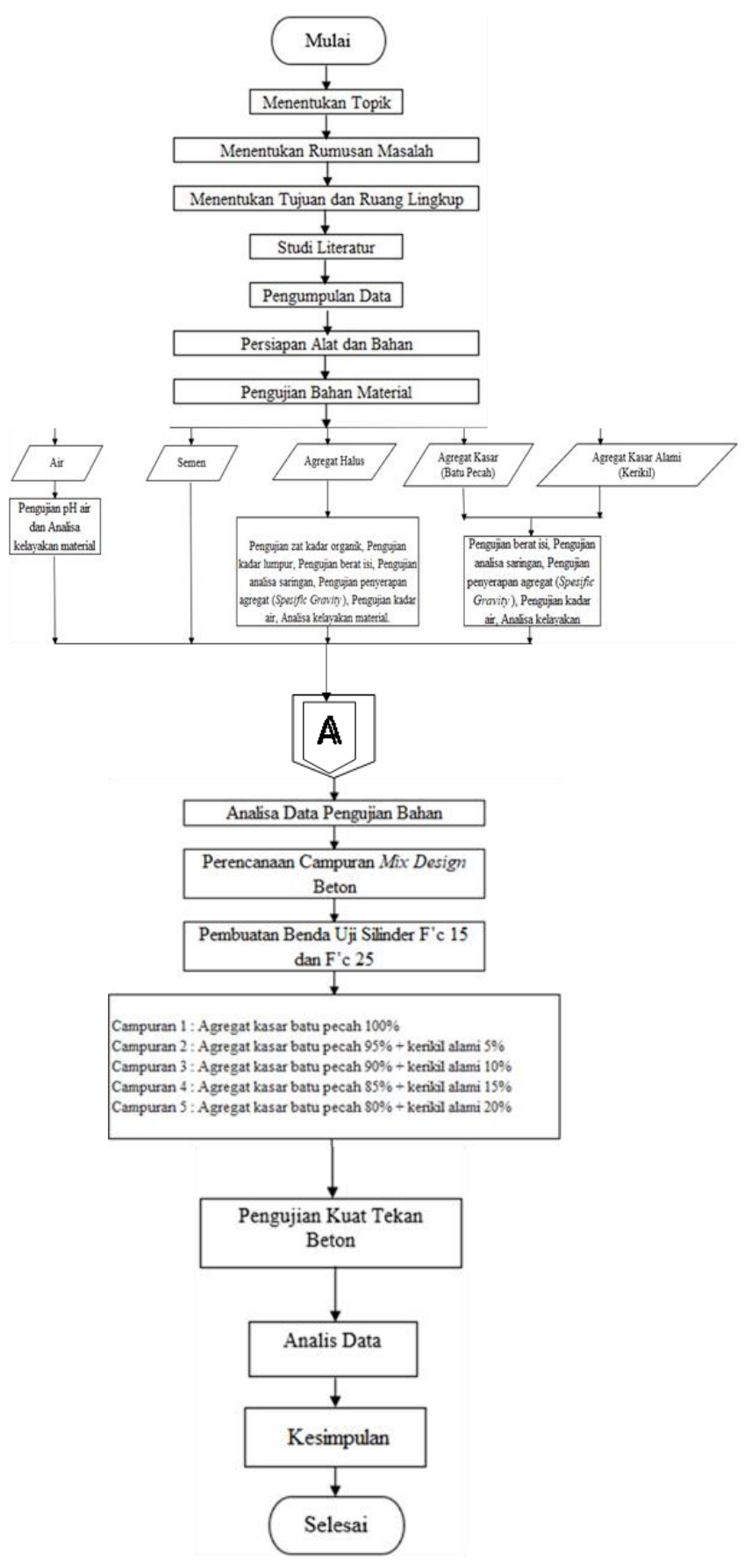

Gambar 1: Bagan Alir Penelitian

4) Lokasi Penelitian 
Untuk penelitian pembuatan beton ini dilaksanakan di Laboratorium Sekolah Tinggi Teknologi Garut Program Studi Teknik Sipil.

5) Metode Pengumpulan Data

Dalam penyusunan skripsi ini metode pengumpulan data yang digunakan adalah dengan melakukan studi literatur dan pengujian labolatorium. Studi literatur bertujuan mempelajari teori-teori yang telah ada baik itu dari literatur buku, jurnal penelitian ataupun lain sebagainya, sehingga mempunyai gambaran untuk membuat penelitian ini.

6) Tahapan Penelitian

Tahapan penelitian ini menjelaskan bagaimana langkah-langkah yang dilakukan dalam penelitian pembuatan beton dari mulai tahapan persiapan sampai selesainya pembuatan beton ini. Untuk langkahlangkah pada tahapan penelitian ini dapat dilihat sebagai berikut.

a. Persiapan alat dan bahan penelitian;

b. Melakukan pemeriksaan bahan campuran beton;

c. Perencanaan campuran beton f'c $20 \mathrm{Mpa}$;

d. Pengujian slump;

e. Berat isi beton segar;

f. Perawatan beton;

g. Pengcappingan beton;

h. Pengujian kuat tekan beton.

\section{HASIL DAN PEMBAHASAN}

\section{A. Pengujian Bahan Campuran Beton}

Pengujian bahan untuk campuran pembuatan beton meliputi pengujian agregat halus, pengujian agregat kasar, pengujian limbah keramik dan pengujian berat jenis semen [7]. Sementara itu dalam penelitian ini untuk data pengujian bahan luar yaitu Dinas PUPR Kabupaten Garut, sedangkan untuk data hasil pengujian berat jenis semen diperoleh dari Laboratorium Rekayasa Beton Politeknik Negri Bandung, hanya pengujian agregat kasar kerikil alamisaja yang mekukan pengujian sendiri. Pengujian bahan ini dilakukan dengan tujuan untuk mengetahui apakah bahan yang digunakan tersebut layak atau tidak untuk dijadikan bahan campuran pembuatan beton. Pengujian bahan tersebut dilakukan dengan syarat dan ketentuan yang berlaku yaitu sesuai SNI [8]. Untuk hasil pengujian bahan beton bisa dilihat pada Tabel.

Tabel 1: Hasil Pengujian Bahan Campuran Beton [9]

\begin{tabular}{llcccl}
\hline No & Jenis Penguijian & $\begin{array}{c}\text { Agregat } \\
\text { Halus }\end{array}$ & $\begin{array}{c}\text { Agregat } \\
\text { Kasar }\end{array}$ & $\begin{array}{c}\text { Kerikil } \\
\text { Alami }\end{array}$ & Ketrangan \\
\hline 1 & Berat Jenis & & & & \\
& Bj. Curah (bulk) & 2,71 & 2,45 & 2,45 & Memenuhi \\
& Bj. SSD & 2,84 & 2,55 & 2,55 & \\
& Bj. Apparent & 3,10 & 2,71 & 2,71 & Memenuhi \\
\hline 2 & Berat Isi & & & & \\
& Gembur & $1,302 \mathrm{~kg} / \mathrm{lt}$ & $1,288 \mathrm{~kg} / \mathrm{lt}$ & $1,288 \mathrm{~kg} / \mathrm{lt}$ & Memenuhi \\
& Padat & $1,592 \mathrm{~kg} / \mathrm{lt}$ & $1,481 \mathrm{~kg} / \mathrm{lt}$ & $1,481 \mathrm{~kg} / \mathrm{lt}$ & Tidak \\
\hline 3 & Kadar Lumpur & $2,61 \%$ & - & - & Memenuhi \\
\hline 4 & Penyerapan Air & $4,60 \%$ & $3,92 \%$ & $7,87 \%$ & Memenuhi \\
\hline 5 & Modulus & 3,39 & - & - & \\
& Kehalusan & & & &
\end{tabular}

Dapat disimpulkan dari data yang ditunjukan diatas bahwa bahan dari kerikil alami hampir seluruhnya 
memenuhi syarat dan ketentuan yang berlaku terkecuali untuk jenis pengujian penyerapan air tidak memenuhi, karena nilainya melebihi batas yang disyaratkan.

Tabel 2: Hasil Pengujian Berat Jenis Semen Semen [10]

\begin{tabular}{lcccc}
\hline \multicolumn{1}{c}{ Berat Contoh } & Notasi & I & II & III \\
\hline Berat benda uji $(\mathrm{gr})$ & $\mathrm{W}$ & 60,11 & 60,06 & 63,9 \\
\hline Volume awal $(\mathrm{ml})$ & $\mathrm{V} 1$ & 0,1 & 0,1 & 0 \\
\hline Volume akhir $(\mathrm{ml})$ & $\mathrm{V} 2$ & 20,7 & 20,6 & 21,4 \\
\hline Berat jenis semen $(\mathrm{gr} / \mathrm{ml})$ & $\frac{\mathrm{W}}{2}$ & 2,9 & 2,92 & 2,94 \\
& \multicolumn{2}{c}{$\mathrm{V} 2-\mathrm{V} 1)$} & & \\
\hline
\end{tabular}

\section{B. Perhitungan Mix Design}

Perhitungan mix design pada penelitian ini mengacu kepada SNI 7656-2012, setelah melakukan perhitungan mix design bahwa bahan yang dibutuhkan untuk campuran beton per 3 sampel dapat dibawah ini.

Tabel 3: Proporsi Bahan Per 3 Sampel

\begin{tabular}{ccccccc}
\hline Jenis & $\begin{array}{c}\text { Agregat } \\
\text { Kasar }\end{array}$ & $\begin{array}{c}\text { Kerikil } \\
\text { alami }\end{array}$ & $\begin{array}{c}\text { Agregat } \\
\text { Halus }\end{array}$ & Air & Semen & Satuan \\
\hline Dasar & 16,244 & & 12,762 & 2,877 & 4,440 & $\mathrm{~kg}$ \\
\hline $5 \%$ & 15,432 & 0,812 & 12,720 & 2,877 & 4,440 & $\mathrm{~kg}$ \\
\hline $10 \%$ & 13,889 & 2,355 & 12,639 & 2,877 & 4,440 & $\mathrm{~kg}$ \\
\hline \hline $15 \%$ & 11,805 & 4,439 & 12,531 & 2,877 & 4,440 & $\mathrm{~kg}$ \\
\hline
\end{tabular}

\section{Pengujian Slump}

Pemeriksaan terhadap nilai slump ini dilakukan setelah campuran pada beton segar terlihat homogen dan tercampur rata. Tujuan dilakukannya pemeriksaan nilai slump adalah untuk Untuk hasil dari pengujian slump pada penelitian ini.

Tabel 4: Nilai Slump Test

\begin{tabular}{cccc}
\hline Campuran & $\begin{array}{c}\text { Nilai Slump } \\
(\mathbf{m m})\end{array}$ & Penambahan Air (Kg) & Keterangan \\
\hline Normal & 75 & 0,13 & Memenuhi \\
\hline Kerikil alami 5\% & 75 & 0,18 & Memenuhi \\
\hline Kerikil Alami 10\% & 75 & 0,20 & Memenuhi \\
\hline \hline Kerikil Alami 15\% & 90 & 0,20 & Memenuhi \\
\hline
\end{tabular}

Dari semua hasil pengujian slump pada tiap campuran beton dapat diambil kesimpulan rencana slump meliputi nilai slump yaitu $75-100 \mathrm{~mm}$.

\section{Pengujian Bobot Isi Beton Segar}

Untuk perhitungan bobot isi dari beton segar ini mengacu kepada SNI 1973:2008. Berikut ini merupakan hasil bobot isi dari beton segar, dilihat dibawah ini. 


\begin{tabular}{|c|c|c|c|c|}
\hline Campuran & $\operatorname{Mm}(\mathbf{K g})$ & Mc (Kg) & $\operatorname{Vm}\left(\mathbf{M}^{3}\right)$ & $\mathrm{D}\left(\mathrm{Kg} / \mathrm{m}^{3}\right)$ \\
\hline \multicolumn{5}{|c|}{ Beton normal } \\
\hline 1 & 11,16 & 23,26 & 0,0053 & 2283,56 \\
\hline 2 & 11,25 & 23,36 & 0,0053 & 2285,44 \\
\hline 3 & 11,14 & 23,08 & 0,0053 & 2253,36 \\
\hline \multicolumn{5}{|c|}{ Kerikil Alami 5\% } \\
\hline 4 & 11,14 & 23,02 & 0,0053 & 2242,04 \\
\hline 5 & 10,9 & 22,98 & 0,0053 & 2279,78 \\
\hline 6 & 11,44 & 23,42 & 0,0053 & 2260,91 \\
\hline \multicolumn{5}{|c|}{ Kerikil Alami $10 \%$} \\
\hline 7 & 10,54 & 22,48 & 0,0053 & 2253,36 \\
\hline 8 & 11,08 & 23,12 & 0,0053 & 2272,23 \\
\hline 9 & 11,4 & 23,29 & 0,0053 & 2243,93 \\
\hline \multicolumn{5}{|c|}{ Kerikil Alami $15 \%$} \\
\hline 10 & 10,72 & 22,7 & 0,0053 & 2260,91 \\
\hline 11 & 10,6 & 22,6 & 0,0053 & 2264,69 \\
\hline 12 & 11,26 & 23,32 & 0,0053 & 2276,01 \\
\hline \multicolumn{5}{|c|}{ Kerikil Alami 20\% } \\
\hline 13 & 11,1 & 23,36 & 0,0053 & 2294,88 \\
\hline 14 & 11,18 & 23,33 & 0,0053 & 2272,23 \\
\hline 15 & 10,96 & 22,94 & 0,0053 & 2260,91 \\
\hline
\end{tabular}

Dari hasil pengujian bobot isi beton segar pada tabel 4.5 diatas, diperoleh nilai bobot isi yang paling besar pada campuran beton normal sampel ke 2 yaitu sebesar $2283,56 \mathrm{~kg} / \mathrm{m}^{3}$, nilai ini memenuhi berat isi rencana yaitu $2285 \mathrm{~kg} / \mathrm{m}^{3}$. Sementara untuk nilai bobot isi yang paling terkecil ada pada campuran kerikil alami pada sampel ke 2 yaitu sebesar $2242,04 \mathrm{~kg} / \mathrm{m}^{3}$.

\section{E. Pengujian Kuat Tekan Beton}

Pada penelitian ini pengujian kuat tekan dilakukan setelah beton mencapai umur 14 hari. Untuk nilai rata-rata kuat tekan pada beton normal diperoleh sebesar 10,67 MPa, nilai tersebut merupakan hasil dari evaluasi nilai kuat tekan rata-rata pada beton normal dari 8 orang yang melakukan penelitian, kemudian nilai kuat tekan tersebut digabungkan dan dirata-ratakan [11]. Untuk rencana kuat tekan yang ditargetkan di laboratorium dalam penelitian ini sebesar 22,624 MPa, akantetapi setelah melihat hasil dari kuat tekan beton normal dari penjelasan sebelumnya mengindikasikan target kuat tekan beton tidak tercapai. Sementara itu untuk hasil kuat tekan beton dengan menggunakan campuran limbah keramik dengan melakukan pembatasan nilai $\pm 5 \%$ untuk hasilnya dapat dilihat sebagai berikut.

Tabel 6: Rata-Rata Nilai Hasil Pengujian Kuat tekan Beton

\begin{tabular}{cccc}
\hline Nama Benda Uji & Umur Benda Uji (Hari) & $\begin{array}{c}\text { Kuat Tekan } \\
\text { (MPa) }\end{array}$ & Nilai Rata-Rata (MPa) \\
\hline KA-5\% & \multicolumn{1}{c}{11,60} \\
\cline { 2 - 3 } & \multirow{2}{*}{14} & 12,16 & 11,60 \\
\hline KA-10\% & & 11,03 & 11,88 \\
\cline { 3 - 4 } & & 12,48 & \\
\hline & & 11,44 & 11,60 \\
\hline
\end{tabular}




\begin{tabular}{|c|c|c|}
\hline Nama Benda Uji Umur Benda Uji (Hari) & $\begin{array}{c}\text { Kuat Tekan } \\
\text { (MPa) }\end{array}$ & Nilai Rata-Rata (MPa) \\
\hline KA-15\% & $\begin{array}{c}12,73 \\
9,33\end{array}$ & \\
\hline
\end{tabular}

Kondisi nilai kuat tekannya naik turun tentunya harus dibuat grafik trendline untuk dianalisis supaya dapat mengetahui pengaruh dari capuran limbah keramik sebagai penggati sebagian dari agregat kasar normal itu apakah terjadi kenaikan atau penurunan. Untuk analisis grafik trendline dapat dilihat pada Gambar 2.

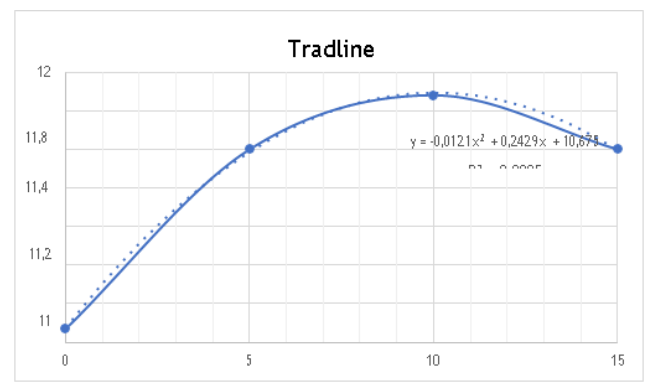

Gambar 2: Grafik Trendline

Dari hasil grafik trendline dapat disimpulkan bahwa nilai kuat tekan rata-rata beton dengan campuran kerikil alami sebagai pengganti sebagian dari agregat kasar normal mengalami penurunan seiring bertambahnya persentase campuran limbah keramik. Tidak hanya itu saja dari grafik trendline diatas diperoleh nilai persamaan regresi yaitu $y=0,0121 x^{2}+0,2429 x+10,675$. Setelah itu nilai kuat tekan beton kemudian dihitung berdasarkan nilai persamaan regresi yang diperoleh dari grafik trendline pada Gambar 2, untuk hasil perhitungannya disajikan pada Tabel 7.

Tabel 7: Kuat Tekan Beton Berdasarkan Persamaan

\begin{tabular}{|c|c|c|}
\hline No & Tipe Perkuatan & $\begin{array}{c}\text { Nilai Kuat Tekan Berdasarkan Persamaan Kuadrat } \\
Y=-0,0121 x^{2}+0,2429 x+10,675(M p a)\end{array}$ \\
\hline 1. & Beton Normal & 10.675 \\
\hline 2. & Kerikil Alami 5\% & 11,587 \\
\hline 3. & Kerikil Alami 10\% & 11,894 \\
\hline 4. & Kerikil Alami 15\% & 11,596 \\
\hline
\end{tabular}

Setelah dilakukan perhitungan kuat tekan beton sesuai rumus ini maka nilai kuat tekan beton biasa adalah $10,65 \mathrm{MPa}$, dan nilai kuat tekan beton yang mengandung campuran kerikil alam 5\% adalah 11,587 MPa yang akan meningkat sebesar $0,96 \%$ menjadi kuat tekannya. nilai beton biasa. Untuk beton dengan campuran kerikil alam $10 \%$ nilai kuat tekannya adalah $11.894 \mathrm{MPa}$ yang akan meningkat sebesar $0.99 \%$. Sedangkan nilai kuat tekan beton dengan campuran $15 \%$ kerikil alam adalah $11.596 \mathrm{MPa}$, yang diturunkan dari $0,29 \%$ pada campuran $5 \%$ dan $10 \%$.

\section{KESIMPULAN DAN SARAN}

\section{A. Kesimpulan}

Berdasarkan hasil penelitian, analisis dan pembahasan data, diperoleh kesimpulan sebagai berikut ini:

1) Data uji materi yang digunakan dalam penelitian ini telah memenuhi berdasarkan SNI;

2) Hasil uji berat beton segar menunjukkan nilai rata-rata $2266,95 \mathrm{~kg} / \mathrm{m} 3$ yang relatif sama dengan perencanaan yaitu $2250 \mathrm{~kg} / \mathrm{m} 3$;

3) Nilai slump untuk campuran Beton Normal di dapat nilai slump $75 \mathrm{~mm}$, untuk campuran kedua dengan bahan tambah Kerikil Alami sebesar 5\% didapat nilai slump 75 mm, untuk campuran ketiga dengan bahan 
tambah Kerikil Alami sebesar 10\% didapat nilai slump $75 \mathrm{~mm}$ dan untuk campuran terahir dengan bahan tambah Kerikil Alami 15\% didapat nilai slump $90 \mathrm{~mm}$ dan dari keempat campuran tersebut memenuhi slump rencana $75-100 \mathrm{~mm}$;

4) Terjadinya kenaikan kekuatan sampai dicapai kekuatan maksimum dimungkinkan oleh terjadinya beton yg lebih padat karena kerikil alami memberikan kemudahan pengerjaan (workability);

5) Terjadinya Penurunan kekuatan setelah dicapai kekuatan maksimum dikarenakan kekuatan lekat (bonding) antara mortar dengan permukaan agregat kasar menjadi berkurang, jika substitusi dengan kerikil alami prosentasenya semakin besar;

6) Hasil analisis Tradline berdasarkan data nilai kuat tekan menunjukkan adanya peningkatan kuat tekan beton yang diberi Subtitusi Kerikil Alami sebagai berikut:

a. Pada Campuran Kerikil Alami sebesar 5\% mengalami kenaikan sebesar 0,96\% atau sebesar $11,587 \mathrm{Mpa}$;

b. Pada Campuran Kerikil Alami Sebesar 10\% mengalami kenaikan sebesar 0,99\% atau sebesar 11,894 Mpa dari kekuatan beton normal;

c. Pada Campuran Kerikil Alami sebesar 15\% mengalami kenaikan sebesar 0,29\% atau sebesar $11,596 \mathrm{Mpa}$

7) Kuat tekan maksimum senilai 11,894 MPa terjadi pada subtitusi optimum kerikil alami 10,03719\%.

\section{B. Saran}

Dari hasil penelitian ini penulis menyadari kemungkinan masih adanya kekurangan, maka dari itu saran yang dapat diambil pada penelitian ini adalah seagai berikut:

1) Data hasil pengujian agregat, semen dan sebagainya seharusnya berupa data primer hasil pengujian sendiri jangan diambil berdasarkan data sekunder dari sumber yang ada;

2) Saat pengecoran, cetakan harus diselesaikan dengan benar sesuai langkah- langkahnya agar beton dapati merata antara sampel 1 dan sampel lainnya. Karena bila campuran beton tidak merata maka akan berpengaruh pada proses uji kuat tekan dan membuat beton mudah hancur pada bagian yang tidak rata;

3) Penelitian perlu di lanjutkan lebih mendalam guna untuk menemukan nilai perbandingan yang lebih akurat dikarenakan mutu beton normal tidak tercapai;

4) Perlu adanya penelitan lebih lanjut mengenai Kerikil Alami sebagai campuran bahan subtitusi beton karena Kerikil Alami pada setiap tempat terbentuk dengan geologis yang berbeda.

\section{DAFTAR PUSTAKA}

[1] Badan Standarisasi Nasional, SNI 1726:2019Tata Cara Perencanaan Ketahanan Gempa Untuk Struktur Bangunan Gedung dan Non Gedung. Jakarta: Badan Standarisasi Nasional, 2019.

[2] Antoni and Nugraha, Teknologi Beton. Yogyakarta: Andi Offset, 2007.

[3] L. J. Murdock and K. M. Brook, Bahan dan Praktek Beton. Jakarta: Erlangga, 1984.

[4] T. Mulyono, Teknologi Beton. Jakarta: FT UNJ, 2003.

[5] Kementerian Pekerjaan Umum Dan Perumahan Rakyat, "Rancangan Campuran Beton." Pusat Pendidikan Dan Pelatihan Jalan, Perumahan, Permukiman Dan Pengembangan Infrastruktur Wilayah, Jakarta, 2017.

[6] R. B. Alkam, "Pengaruh Variasi Waktu Pembebanan Terhadap Sifat Reologi Visco-Elastic Aspal Pen 80/100 Dengan Penambahan Asbuton Murni," J. Tek. Sipil, vol. 14, no. 4, pp. 208-218, 2018.

[7] Badan Standarisasi Nasional, "SNI 03-6861.1-2002 Tentang Spesifikasi Bahan Bangunan Bagian A (Bahan Bangunan Bukan Logam).” Badan Standarisasi Nasional, Jakarta, p. 6861, 2002.

[8] S. Supratikno and R. Ratnanik, "Pemanfaatan Limbah Plastik Sebagai Pengganti Agregat Kasar pada Adukan Beton," J. Tek. Sipil ITP, vol. 6, no. 1, pp. 21-29, 2019, doi: 10.21063/jts.2019.v601.04.

[9] Dinas PUPR Kabupaten Garut, "Hasil Pengujian Bahan Campuran Beton," Garut, 2019.

[10] Politeknik Negeri Bandung, "Hasil Pengujian Berat Jenis Semen Semen," Bandung, 2019.

[11] Y. Wulandari, "Studi Komparasi Pemanfaatan Batu Pecah Tangan Dan Stone Crusher Terhadap Sifat Marshall Dan Workability Pada Campuran Hrs-Base," Universitas Muhammadiyah Surakarta, 2018. 